\title{
Survival of 16 alfalfa populations space planted into a grassland
}

\author{
JOHN R. HENDRICKSON AND JOHN D. BERDAHL
}

Authors are Rangeland Scientist and Plant Geneticist Northern Great Plains Research Laboratory, USDA-ARS, Box 459 Mandan, North Dakota 58554.

\begin{abstract}
Many alfalfa (Medicago spp.) cultivars have limited ability to persist under grazing and therefore, a key step in incorporating alfalfa into pastures and rangelands is choosing a grazing tolerant cultivar. In this study, we evaluated the grazing tolerance of 16 alfalfa populations representing a range of potential grazing tolerance. Entries were transplanted on a rangeland site in July 1996 at the Northern Great Plains Research Lab in Mandan, N.D., USA and mob-grazed by cattle from 1997 to 2000 . Plant survival, basal area, and stem numbers were recorded in the spring and fall of each year. At the final survival evaluation in May 2001, SCMF 3713 had the highest survival (90\%), 'Vernal' had the lowest $(23 \%)$ and 10 of the 16 entries had greater than $50 \%$ survival. A large decline in survival between September 2000 and May 2001 may be attributed to low temperatures in November and December of 2000. Entries such as 'Alfagraze', B36 and Agripro ZG9415, which were developed in warmer climates, had the largest percentage drop in survival $(43.0,48.6$, and 48.6 percentage points respectively) while SCMF 3713, 'Anik' and Alaska Syn A, developed in colder climates, had the least percentage point drops $(2.8,4.1$, and 4.1 respectively). The ability to survive over winter contributed more to the different survival rates of these alfalfa populations than did any of the measured plant variables. Producers should know the origins of grazing tolerant alfalfa cultivars and consider selecting cultivars that have been tested in their area.
\end{abstract}

Key Words: Medicago sativa ssp. falcata, mob-grazing, cold tolerance, grazing tolerance

Incorporating alfalfa into grasslands can improve the quality and quantity of available forage in the Northern Great Plains (Lorenz 1982, Heinrichs 1975) resulting in better animal performance and higher carrying capacity (Van Keuren and Matches 1988). Alfalfa can also improve nutrition later in the growing season when many of the perennial grasses experience a quality decline (Sanderson and Wedin 1989). Alfalfa has difficulty in persisting under livestock grazing in the Northern Plains (Bittman

The U.S. Department of Agriculture, Agriculture Research Service, Northern Plains Area, is an equal opportunity/affirmative action employer and all agency services are available without discrimination. The authors would like to thank G. Jensen, B. Wald, M.K. Tokach, L. Hatzenbuhler and W. Manchester for their help in data collection and J. Karn, A. Singh, P. Jefferson and 3 anonymous reviewers for their comments on an earlier version of the manuscript. Mention of product names in this document does not indicate endorsement by the USDA-ARS.

Manuscript Accepted 17 Jul. 02

\section{Resumen}

Muchos cultivares de alfalfa (Medicago spp.) tienen una capacidad limitada para persistir bajo apacentamiento, y por lo tanto, un paso clave para incorporar la alfalfa en praderas y pastizales es el elegir un cultivar tolerante al apacentamiento. En Este estudio evaluamos la tolerancia al apacentamiento de $\mathbf{1 6}$ poblaciones de alfalfa representando un rango de la tolerancia al apacentamiento. En Julio de 1996 se transplantaron las entradas de alfalfa en un sitio de pastizal del El laboratorio de Investigación Northern Great Plains en Mandan, N.D., USA y que fue apacentado por ganado de 1997 al 2000 . En primavera y otoño de cada año se registro la supervivencia de plantas, el área basal y el número de tallos. En la evaluación final de supervivencia, en Mayo de 2001, la entrada SCMF 3713 tuvo la mas alta supervivencia ( $90 \%)$, el cultivar 'Vernal' tuvo la más baja $(23 \%)$ y 10 de las 16 entradas tuvieron un porcentaje de supervivencia mayor de $50 \%$. Una gran disminución de supervivencia ocurrida entre Septiembre de 2000 y Mayo de 2001 puede ser atribuida a las bajas temperaturas de Noviembre y Diciembre de 2000. Entradas tal como 'Alfagraze', B-36 y Agripro ZG9415, las cuales fueron desarrolladas en climas cálidos, tuvieron el mayor porcentaje de caída de supervivencia $(43.0,48.6$ y $48.6 \%$ respectivamente) mientras que las entradas SCMF 3713, 'Anik' y Alaska Syn A, desarrolladas en climas fríos, tuvieron los menores porcentajes de caída de supervivencia $(2.8,4.1$ y 4.1 respectivamente). La capacidad para sobrevivir en el invierno contribuyó más en el diferencial de las tasas de supervivencia de estas poblaciones de alfalfa que cualquier otra de las variables medidas en la planta. Los productores deben conocer el origen de los cultivares de alfalfa tolerantes al apacentamiento y considerarlo en la selección de los cultivares que van a ser probados en su área.

and McCartney 1994). A first step in incorporating alfalfa into rangelands is to determine cultivars that can withstand livestock grazing pressure. Cultivars with a high proportion of Medicago sativa ssp. falcata parentage have been demonstrated to improve the persistence of alfalfa under grazing (Berdahl et al. 1989, Bittman and McCartney 1994).

The ability to persist under livestock grazing has been suggested as an important selection criteria in development of alfalfa cultivars (Brummer and Moore 2000). Selection of surviving plants under heavy, continuous grazing has been shown to improve the grazing tolerance of alfalfa (Smith et al. 1989, Smith and Bouton 1993). Much of this work has been done in monoculture situations where competition is intra-specific rather than inter-specific. Long-term trials where cultivars are grown in competition 
with grasses may be necessary to identify superior cultivars for use in pastures and rangelands (Berdahl et al. 1989, Bittman et al. 1991).

Morphological traits have been shown to improve grazing resistance in grasses (Briske 1991). Understanding plant traits that may influence grazing persistence in alfalfa would be beneficial to forage breeders and managers alike. Traits such as prostrate growth, thin stems and low yield (Brummer and Bouton 1991) as well as the ability to produce new plants from root propagules (Heinrichs 1963, Berdahl et al. 1986) have been associated with grazing tolerant alfalfas. Alfagraze, however, has shown excellent grazing tolerance (Smith et al. 1989, Smith and Bouton 1993, Brummer and Moore 2000) and yet has high yield, intermediate decumbency, and many, thick stems (Brummer and Bouton 1991).

Fall dormancy is determined by measuring the amount of regrowth that occurs 25 to 30 days after an appropriate final clipping date in the fall (Teuber et al. 1998). There is a close association between winterhardiness of cultivars and fall dormancy (McKenzie et al. 1988). Because of this, fall dormancy is often used as a means of determining the suitability of a cultivar for a climatic regime (Melton et al. 1988).

The first step in successfully incorporating alfalfa into rangelands in the Northern Great Plains is to choose an appropriate cultivar. Our objective in this study was to evaluate the survival of 16 different cultivars and strains of alfalfa that were grown in association with grass and grazed.

\section{Material and Methods}

This study was conducted at the Northern Great Plains Research Laboratory located approximately $6 \mathrm{~km}$ south of Mandan, N.D. $\left(46^{\circ} 46^{\prime} \mathrm{N} 100^{\circ} 50^{\prime}\right.$ W). Sixteen cultivars and strains of alfalfa were transplanted into a native rangeland in July 1996. Alfalfa plants were started from seed in cone-tainers (Stewe and Sons, Corvallis, Ore.) and were 3 months old when transplanted into the site. The rangeland had not been grazed for at least 15 years prior to the study and the vegetation was dominated by smooth bromegrass (Bromus inermus Leyss.). Native species present included blue grama [Bouteloua gracilis (H.B.K.) Lag. ex. Steud.], little bluestem [Schizachyrium scoparium (Michx.) Nash], praire coneflower [Ratibida columnifera (Nutt.) Woot.\& Standl.], cudweed sagewort (Artemisia

Table 1. Information about alfalfa entries in the grazing study. Comments include use and origin. Dormancy indicates the estimated fall dormancy rating.

\begin{tabular}{|c|c|c|}
\hline Entry & Comments & Dormancy \\
\hline Vernal & $\begin{array}{l}\text { Standard Hay-type Cultivar, Medicago sativa subsp. x } \\
\text { varia, University of Wisconsin }\end{array}$ & 2 \\
\hline Ladak 65 & $\begin{array}{l}\text { Hay and Pasture type, } M \text {. sativa subsp. x varia, Montana } \\
\text { State University }\end{array}$ & 1 \\
\hline Travios & Grazing type, $M$. sativa subsp. $\mathrm{x}$ varia, South Dakota State University & 1 \\
\hline Rangelander & $\begin{array}{l}\text { Grazing type, } M \text {. sativa subsp. x varia, Agriculture and Agri-Food } \\
\text { Canada, Swift Current, Saskatchewan }\end{array}$ & 1 \\
\hline Spredor 3 & Grazing type, $M$. sativa subsp. x varia Northup-King & 1 \\
\hline Alfagraze & $\begin{array}{l}\text { Grazing type, M. sativa subsp. } \mathrm{x} \text { varia Developed by } \\
\text { University of Georgia, Distributed by America's Alfalfa }\end{array}$ & 2 \\
\hline ZG9415 & $\begin{array}{l}\text { Grazing type, } M \text {. sativa subsp. x varia, Experimental, } \\
\text { Developed under grazing in Missouri, AgriPro Seeds }\end{array}$ & $\begin{array}{l}2 \\
1\end{array}$ \\
\hline Anik & $\begin{array}{l}\text { Grazing type, } M \text {. sativa subsp. falcata, Agriculture and } \\
\text { Agri-Food Canada, Beaverlodge, Alberta }\end{array}$ & \\
\hline Mandan 3851 & $\begin{array}{l}\text { Grazing type, } M \text {. sativa subsp. x varia, Experimental, USDA-ARS } \\
\text { Mandan, N.D. }\end{array}$ & 1 \\
\hline $\begin{array}{l}\text { Mandan } \\
\text { Grasshopper } \\
\text { Preference }\end{array}$ & $\begin{array}{l}\text { Collected from a grasshopper preference study, } \text { M. sativa } \\
\text { subsp. x varia, Experimental, USDA-ARS, Mandan, N.D. }\end{array}$ & 1 \\
\hline SCMF3713 & $\begin{array}{l}\text { Grazing type, } M \text {. sativa subsp. falcata, Experimental, Agriculture } \\
\text { and Agri-Food Canada, Swift Current, Saskatchewan }\end{array}$ & 1 \\
\hline Alaska Syn A & $\begin{array}{l}\text { Hay and pasture type, } M \text {. sativa subsp. x varia, Institute of } \\
\text { Agriculture, University of Alaska and USDA-ARS, Palmer, Alask.a }\end{array}$ & 1 \\
\hline B-36 & $\begin{array}{l}\text { Experimental, Decumbent Growth, } M \text {. sativa subsp. x varia, } \\
\text { Collected in Turkey, USDA-ARS Beltsville, Maryland }\end{array}$ & $\begin{array}{l}3 \\
1\end{array}$ \\
\hline $\mathrm{C}-27$ & $\begin{array}{l}\text { Mixture of } 2 \mathrm{X} \text { and } 4 \mathrm{X} M \text {. sativa subsp. falcata, USDA-ARS } \\
\text { and Colorado Agricultural Experiment Station }\end{array}$ & \\
\hline $\mathrm{C}-31$ & $\begin{array}{l}\text { M. sativa subsp. } \mathrm{x} \text { varia, USDA-ARS and Colorado } \\
\text { Agricultural Experiment Station }\end{array}$ & 1 \\
\hline Pioneer 5151 & $\begin{array}{l}\text { Hay and Pasture, } M \text {. sativa subsp. x varia, } \\
\text { Pioneer Hi-Bred International }\end{array}$ & 1 \\
\hline
\end{tabular}

ludoviciana Nutt.), and fringed sagebrush (Artemisia frigida Willd). As the study progressed, Kentucky bluegrass (Poa pratensis L.) began to invade the site.

Fifteen of the entries were selected based on their grazing tolerance and Vernal was used as a check. Entries are described in Table 1. Eight blocks (reps) contained randomly assigned plots of each entry. Each plot contained 9 plants of the same entry space planted on $0.9 \mathrm{~m}$ centers in a $3 \times 3$ matrix. There was a total of 128 plots containing 1,152 plants.

Grazing was conducted using the mob grazing technique (Bittman and McCartney 1994). Four head of yearling steers were placed on the study site and the alfalfa was grazed to an average height of $5 \mathrm{~cm}$. When average regrowth, based on a random subset of all entries, reached approximately $15 \mathrm{~cm}$ or more, grazing was started again. The last grazing event was usually in mid to late September prior to the first frost. There were 3 grazing events in 1997, 5 in 1998, 5 in 1999, and 4 in
2000. In 1997, initial grazing was delayed until 24 July to allow establishment of plants that had been damaged by grasshopper herbivory in 1996. Only 55 plants out of a total of 1,152 had severe damage from grasshoppers and these were replaced in early spring 1997 . After 1997, the first grazing event was started when alfalfa reached the bud stage.

Plant survival was evaluated in May after some regrowth had occurred and in September after the last grazing event in each year. The final survival count was done in May 2001. Each plot was visually surveyed to determine the number of live plants. Plants with some green material remaining were considered as living. Survival was evaluated as the proportion of living plants divided by 9 (the number of original transplants) in each plot. As the study progressed, many entries produced new plants, mainly from horizontal rootstocks. These new plants that emerged in the vicinity of the original plant were counted separately; however, if the origi- 
nal plant had died but there was a new plant in the same vicinity, the plant was considered as alive.

Basal area and stem numbers were determined in the spring and fall of each year except for 1997 . There were relatively minor differences in stem numbers and basal area between entries at the beginning of the study, so data are presented as absolute values. Basal area was measured by using a nylon string to measure plant circumference and this value was converted into basal area with the formula:

$$
\frac{\text { (Basal Circumference) }^{2}}{4 \pi}
$$

Total basal area was determined on each original and daughter plant separately and then summed to get total basal area. Parental basal area was determined on the original plants only. Stem numbers were also determined on parental and total plants.

Temperature data were collected year round from a weather station located 2.4 $\mathrm{km}$ from the study location. Precipitation data from April through October were collected from the same station. Precipitation data from November through March were collected from a National Weather Service station located $4 \mathrm{~km}$ from the study site. This was also the reference site for the long-term (1913-2000) weather data.

Precipitation data were collected for the last 6 months of 1996, all of 1997, 1998, 1999, and 2000 and for the first 5 months of 2001 . Only 1997 , which had $73 \%$ of the long-term average precipitation and the first 5 months of 2001 which had $94 \%$ of the long-term average precipitation were drier than normal. Precipitation during the last 6 months of 1996, and all of 1998, 1999 , and 2000 was $144,127,136$, and $121 \%$ of the long-term average, respectively. Yearly average maximum and minimum temperatures were generally within $1.5^{\circ} \mathrm{C}$ of the long-term average. Exceptions were maximum temperatures during the last 6 months in 1996 which averaged $4.7^{\circ} \mathrm{C}$ cooler than the long-term average, the minimum for 1998 which averaged $3^{\circ} \mathrm{C}$ warmer than long-term average and the minimum for the first 5 months in 2001 which averaged $2^{\circ} \mathrm{C}$ warmer than the long-term average. Monthly maximum and minimum departures from the long-term average are shown in Figure 1. Maximum tempera- tures for most of the growing season in 1999 were cooler than the long-term average but winter temperatures were warmer than the long-term average. In November and December of 2000, maximum and minimum temperatures were cooler than the long-term average as was the maximum and minimum for February 2001.

Survivorship data were transformed by taking the arc sin of the number of surviving plants in each plot divided by 9 (the number of original plants) and then analyzed using PROC Mixed procedure in SAS (Littell et al. 1996). Entry and year were considered the fixed effects and replicate considered as a random effect. Mean survival data presented for each entry are expressed in non-transformed values (Table 2). Partial correlation coefficients were calculated using the Manova procedure in SAS (1990). Average number of daughter plants, stem numbers and parental, and total basal area for September 2000 were analyzed using Proc Mixed (Littell et al.1996) with the same terms as the survivorship data. Means were separated using the Tukey-Kramer adjusted means procedure at $\mathrm{P}<0.05$.
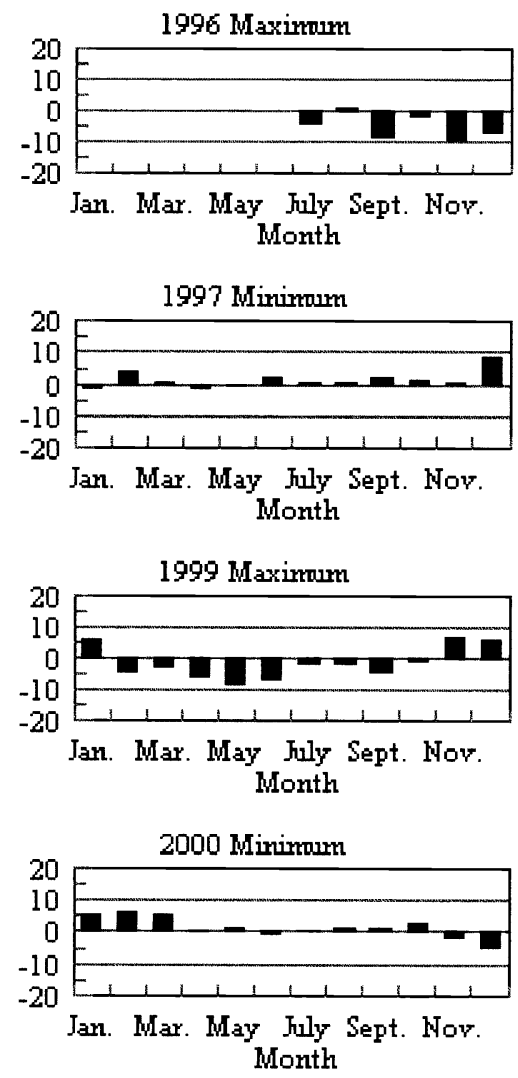
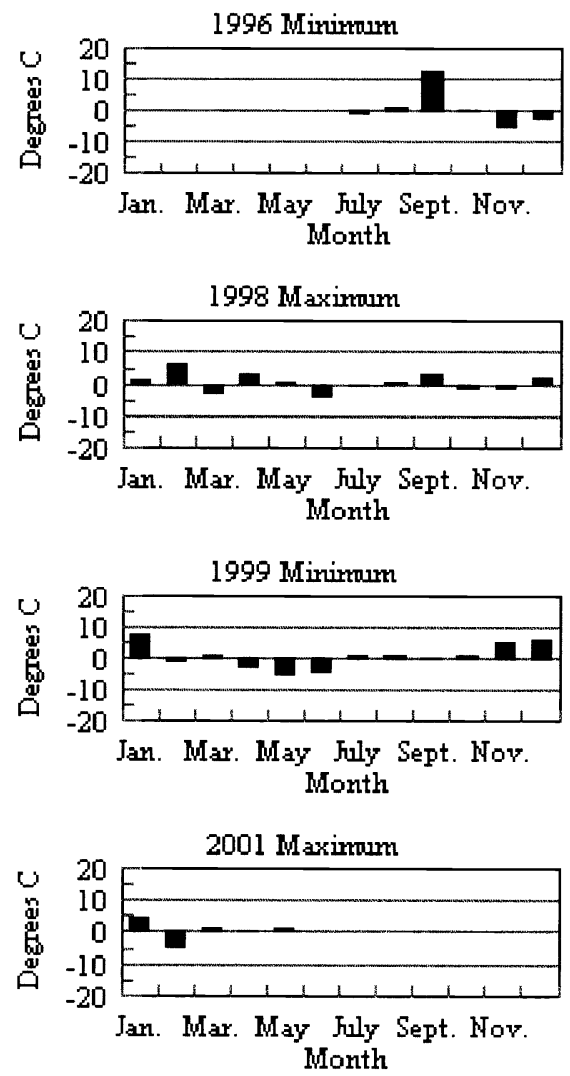
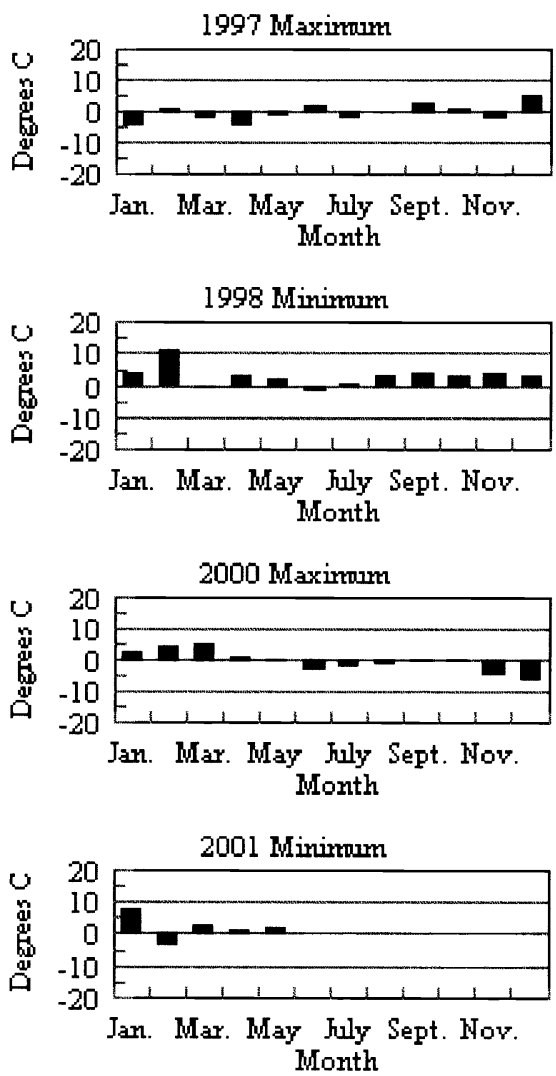

Fig. 1. Monthly departures from long-term average (1913 to 2000) for maximum and minimum temperatures from July 1996 to May 2001 . Y axis indicates departure from long-term average in degrees $C$. 
Table 2. Percent survival in September 2000 and May 2001, decline in percent survival between September 2000 and May 2001 , total basal area in May 2000 and September 2000 and stem numbers in May 2000 of selected alfalfa cultivars. Decline in percent survival is the number of percentage points survival declined between September 2000 and May 2001 . Significant differences between means within a column are noted by different letters.

\begin{tabular}{|c|c|c|c|c|c|c|}
\hline Entry & $\begin{array}{c}\text { September } \\
2000 \\
\text { Survival }\end{array}$ & $\begin{array}{c}\text { May } \\
2001 \\
\text { Survival }\end{array}$ & $\begin{array}{c}\text { Decline in } \\
\text { percentage } \\
\text { points }\end{array}$ & $\begin{array}{c}\text { May } \\
2000 \\
\text { Total Basal Area }\end{array}$ & $\begin{array}{c}\text { September } \\
2000 \\
\text { Total Basal Area }\end{array}$ & $\begin{array}{c}\text { May } \\
2000 \\
\text { Stem } \\
\text { numbers }\end{array}$ \\
\hline & $(\%)$ & $(\%)$ & & $\left(\mathrm{cm}^{2}\right)$ & $\left(\mathrm{cm}^{2}\right)$ & $\left(\right.$ Plant $\left.^{-1}\right)$ \\
\hline Vernal & $45.8 \mathrm{~b}$ & $23.6 \mathrm{~d}$ & 22.2 & 96.1 & $182.9 \mathrm{ab}$ & $12.4 \mathrm{~b}$ \\
\hline Ladak 65 & $72.2 \mathrm{ab}$ & $45.8 \mathrm{bcd}$ & 26.4 & 108.5 & $193.1 \mathrm{ab}$ & $21.2 \mathrm{ab}$ \\
\hline Travois & $85.8 \mathrm{ab}$ & $73.6 \mathrm{abc}$ & 12.2 & 115.0 & $250.1 \mathrm{a}$ & $26.6 \mathrm{a}$ \\
\hline Rangelander & $70.3 \mathrm{ab}$ & 56.9 abcd & 13.4 & 93.4 & $199.9 \mathrm{ab}$ & $20.3 \mathrm{ab}$ \\
\hline Spredor 3 & $84.7 \mathrm{a}$ & $58.3 \mathrm{abcd}$ & 26.4 & 88.7 & $185.0 \mathrm{ab}$ & $16.5 \mathrm{ab}$ \\
\hline Alfagraze & $69.4 \mathrm{ab}$ & $26.4 \mathrm{~d}$ & 43.0 & 83.2 & $170.6 \mathrm{ab}$ & $18.7 \mathrm{ab}$ \\
\hline ZG9415 & $75.0 \mathrm{ab}$ & $26.4 \mathrm{~d}$ & 48.6 & 87.6 & $183.1 \mathrm{ab}$ & $18.6 \mathrm{ab}$ \\
\hline Anik & $81.9 \mathrm{ab}$ & $77.8 \mathrm{ab}$ & 4.1 & 87.2 & $131.9 \mathrm{~b}$ & $21.2 \mathrm{ab}$ \\
\hline Mandan 3851 & $86.1 \mathrm{a}$ & $73.6 \mathrm{abc}$ & 12.5 & 111.0 & $184.2 \mathrm{ab}$ & $23.0 \mathrm{ab}$ \\
\hline Mandan Grasshopper Preference & $63.9 \mathrm{ab}$ & $44.4 \mathrm{bcd}$ & 19.5 & 122.3 & $222.2 \mathrm{ab}$ & $21.0 \mathrm{ab}$ \\
\hline SCMF 3713 & $93.1 \mathrm{a}$ & $90.3 \mathrm{a}$ & 2.8 & 129.8 & $217.4 \mathrm{ab}$ & $25.6 \mathrm{a}$ \\
\hline Alaska Syn A & $83.3 \mathrm{ab}$ & $79.2 \mathrm{ab}$ & 4.1 & 146.8 & $207.5 \mathrm{ab}$ & $20.9 \mathrm{ab}$ \\
\hline B-36 & $86.1 \mathrm{a}$ & $37.5 \mathrm{~cd}$ & 48.6 & 142.0 & $167.4 \mathrm{ab}$ & $18.9 \mathrm{ab}$ \\
\hline C-27 & $61.1 \mathrm{ab}$ & $55.6 \mathrm{abcd}$ & 5.5 & 112.3 & $205.8 \mathrm{ab}$ & $18.3 \mathrm{ab}$ \\
\hline $\mathrm{C}-31$ & $84.7 \mathrm{ab}$ & $77.8 \mathrm{abc}$ & 6.9 & 139.8 & $237.7 \mathrm{ab}$ & $22.2 \mathrm{ab}$ \\
\hline Pioneer 5151 & $80.6 \mathrm{ab}$ & $51.4 \mathrm{bcd}$ & 29.2 & 117.7 & $252.2 \mathrm{a}$ & $25.2 \mathrm{a}$ \\
\hline
\end{tabular}

\section{Results}

Survival declined sharply from September 2000 to May 2001 (Fig. 2). Survival for all entries declined during this period (Table 2), but entries varied in the amount of decline resulting a time by entry interaction. The decline in survival ranged from 48.6 percentage points for ZG9415 and B-36 to 2.8 percentage points for SCMF 3713. Five of the entries had a decline of less than 10 percentage points, 4 of the entries had a decline of 10-20 percentage points, 4 entries had declines of 20-30 percentage points and 3 entries had a decline of over 40 percentage points between September 2000 and May 2001.

Survival of the 16 alfalfa entries in May 2001 ranged from $23 \%$ for Vernal to $90 \%$ for SCMF 3713. Ten of the 16 had survival greater than $50 \%$ (Table 2). Survival of SCMF 3713 was significantly higher ( $P$ $<0.05)$ than Vernal, 'Ladak 65', Alfagraze, ZG9415, Mandan Grasshopper Preference, Beltsville B-36 and 'Pioneer
5151'. Alaska Syn A had significantly higher $(P<0.05)$ survival than Beltsville B-36, ZG9415, Alfagraze and Vernal. Vernal, ZG9415 and Alfagraze had significantly lower $(\mathrm{P}<0.05)$ survival than 'Travois', Anik, Mandan 3851 or C-31 from Colorado.

Total basal area for live plants in May 2000 ranged from a low of $83.24 \mathrm{~cm}^{2}$ for Alfagraze to a high of $146.79 \mathrm{~cm}^{2}$ for Alaska Syn A (Table 2). There was no significant difference among entries in the May 2000 total basal area. Total basal area in September 2000 ranged from $132 \mathrm{~cm}^{2}$ for Anik to $252 \mathrm{~cm}^{2}$ for Pioneer 5151 and there were significant differences $(\mathrm{P}<$ 0.05 ) among entries. Total basal area of Anik was less $(\mathrm{P}<0.05)$ than total basal area of Travois and Pioneer 5151 (Table 2). Total basal area declined during 1997 and 1998 growing seasons and then increased in the 1999 and 2000 growing seasons (data not shown).

Spring 2000 stem numbers ranged from an average of 12.4 for Vernal to 26.6 for
Travois. Vernal had significantly $(\mathrm{P}<$ 0.05) lower stem numbers than did SCMF 3713 and Travois (Table 2). Stem numbers increased during every growing season except for 1997 (data not shown).

All of the plant traits measured had significant but relatively low correlation coefficients with the May 2001 survival (Table 3). May 2001 survival was most strongly correlated $(r=0.46)$ with total basal area in September 2000 , followed by spring stem numbers $(r=0.41)$ and total basal area in the spring of $2000(r=0.35)$. Average number of daughter plants in the spring and fall and fall stem numbers had the lowest correlations with May 2001 survival ( $r$ $=0.25,0.23$ and 0.26 , respectively)

\section{Discussion}

Survival of alfalfa entries in this study exhibited a time by entry interaction, primarily driven by a sharp decline in survival for some entries between September 


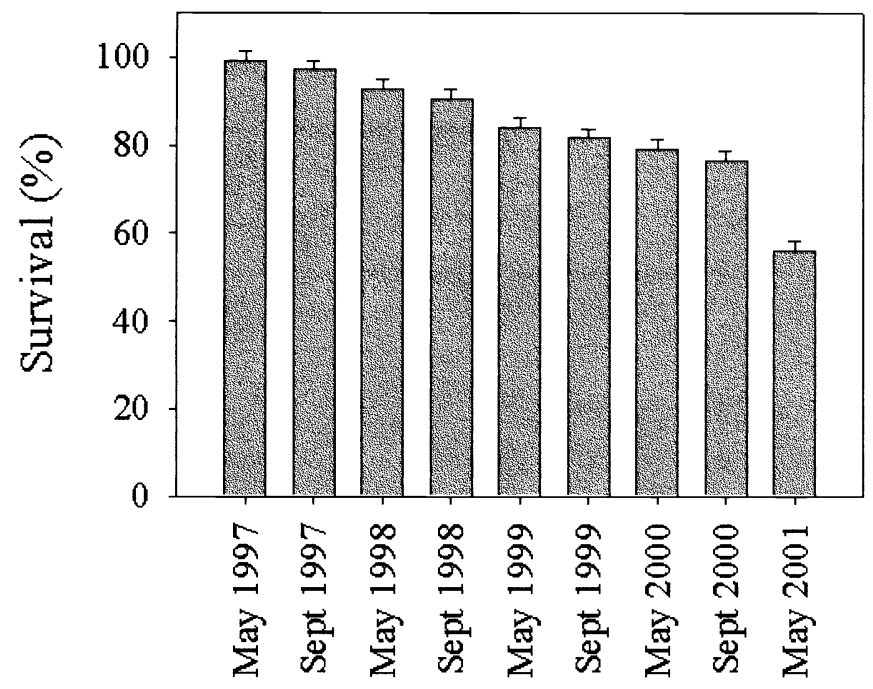

Time

Fig. 2. Average percent survival pooled over entries from May 1997 to May 2001.

2000 and May 2001. Colder than average temperatures in November and December of 2000 as well as February 2001 may have precipitated this decline. There were also several days in mid-April where the temperatures did not exceed $0^{\circ} \mathrm{C}$. The only other comparative period during the study was the winter directly following establishment (November 1996 to April 1997). However during that period, record snowfall, as well as a lack of grazing pressure, may have reduced the impact of the cold temperatures.

While the survival of all entries declined from September 2000 to May 2001, the most dramatic declines were for entries from warmer regions with higher fall dormancy scores. Alfagraze, B-36 and ZG9415 were developed in Georgia, Maryland and Missouri, respectively, and all had declines of over 40 percentage points. These entries all had a fall dormancy score of 2 or higher. Fall dormancy has been identified as a good predictor of alfalfa survival in Minnesota (Sheaffer et al. 1997), and mortality of non-dormant alfalfa is less when the plants have traits associated with fall dormancy such as generally slower growth and larger roots (Hotchkiss et al. 1996). In our study, the small number of entries with dormancy ratings greater than 1 make it difficult to reach any conclusions regarding fall dormancy and survival. However, there were differences in survival among entries with a fall dormancy rating of 1 which may suggest other factors besides fall dormancy affect winter survival. survival. shown to have a higher proportion of determinate taproots than field grown plants (Lamb et al. 2000). Determinate taproots split into 2 or more relatively equal size roots (Lamb et al. 2000). The effect of this on alfalfa survival is unknown and our results may differ from a direct seeded stand.

Traits related to plant size had the strongest positive correlation with survival. Plants that had a larger total basal area in September 2000 or more stems in May 2000 were most likely to survive. The correlations with parental basal area were less strong than those with total basal area (Table 3). Brummer and Bouton (1991) reported that broad crowns were not associated with grazing tolerance in the germplasm they examined, which included Travois and Alfagraze; however, other reports have indicated that broad crown development from rhizome proliferation was associated with survival of alfalfa when grazed (Berdahl et al. 1989). In our study, parental basal area was less strongly correlated with survival than total basal area, which included new plants in the vicinity of the original parental plants. Still, definitive conclusions are difficult because of the wide range in geographic origin of the entries.

It has been suggested that the ability to produce new shoots from horizontal rootstalks may be an important survival mechanism for alfalfa in rangelands (Heinrichs 1963, Berdahl et al. 1986, 1989). For the entries we considered, however, average number of new plants in 2000 was the trait with the lowest correlation with survival. Still, these daughter plants would have contributed to total basal area, which was more strongly correlated with survival.

Plants with more stems in May 2000 were more likely to survive until the following year $(r=0.41)$ but stem numbers in September 2000 were less strongly correlated with survival $(r=0.26)$. Stem numbers increased for all species except Anik between spring and fall (data not

Table 3. Correlation coefficients of various selected plant traits recorded in 2000 with May 2001

\begin{tabular}{lll}
\hline \hline Trait & r value & P value \\
\hline Average number of daughter plants per plot in Spring 2000 & 0.25 & 0.0074 \\
Average number of daughter plants per plot in Fall 2000 & 0.23 & 0.0123 \\
Total Basal Area in Spring 2000 & 0.35 & 0.0002 \\
Parental Basal Area in Spring 2000 & 0.28 & 0.0034 \\
Total Basal Area in Fall 2000 & 0.46 & 0.0001 \\
Parental Basal Area in Fall 2000 & 0.33 & 0.0004 \\
Number of Stems in Spring 2000 & 0.41 & 0.0001 \\
Number of Stems in Fall 2000 & 0.26 & 0.0060 \\
\hline
\end{tabular}


shown) but an increase in stem numbers did not appear to increase survival. For example, stem numbers for Vernal in September 2000 were $170 \%$ greater than in May 2000, but this cultivar had the lowest survival. On the other hand, SCMF 3713 , which had the highest survival, only increased stem numbers over the growing season by $30 \%$. Brummer and Bouton (1991) suggested the high number of crown buds produced by Alfagraze might aid in its persistence. This may indicate why stem numbers in the spring had a stronger correlation with survival than did stem numbers in the fall. Since axillary buds are the source of new shoots in other perennial plants such as grasses (Murphy and Briske 1992), a large population of buds that survive the winter may result in higher stem numbers in the spring.

\section{Implications:}

This study illustrates the need for producers to emphasize not only grazing tolerance but also climatic adaptability when they chose cultivars. It is important to recognize that germplasm with a wide range in genetic background and geographic origin was studied and that selected plant traits generally had low correlations $(r<$ $0.5)$ with survival. Within each measured trait, there were some entries that survived well despite not having a large basal area or number of stems. While the ability to withstand grazing is crucial for grazing tolerant alfalfa cultivars to be successful, in many colder areas the ability to withstand the climatic extremes is also important. Producers should choose cultivars that are not only grazing tolerant but that can withstand the climatic regime in their region. Breeding programs should include adaptation to climate as well as grazing tolerance in their selection criteria.

\section{Literature Cited}

Berdahl, J.D., A.C. Wilton, and A.B. Frank. 1989. Survival and agronomic performance of 25 alfalfa cultivars and strains interseeded into rangeland. J. of Range Manage. 42:312-316.

Berdahl, J.D., A.C. Wilton, R.J. Lorenz, and A.B. Frank. 1986. Alfalfa survival and vigor in rangeland grazed by sheep. J. of Range Manage. 39:59-62.

Bittman, S. and D.H. McCartney. 1994. Evaluating alfalfa cultivars and germplasms for pastures using the mob-grazing technique. Can. J. Plant Sci. 74:109-114.
Bittman, S., J. Waddington, and D.H. McCartney. 1991. Performance of alfalfa strains grown in mixture with smooth bromegrass as affected by management. Can. J. Plant Sci. 71:1029-1037.

Briske, D.D. 1991. Developmental morphology and physiology of grasses. In: Heitschmidt, R. K. and Stuth, J. W. (eds.) Grazing Management: An ecological perspective. Portland, Oregon: Timber Press; 1991: 85-108.

Brummer, E.C. and J.H. Bouton. 1991. Plant traits associated with grazing-tolerant alfalfa. Agron. J. 83:996-1000.

Brummer, E.C. and K.J. Moore. 2000. Persistence of perennial cool-season grass and legume cultivars under continuous grazing by beef cattle. Agron. J. 96:466--471.

Heinrichs, D.H. 1963. Creeping alfalfas. Adv. Agron. 15:317-337.

Heinrichs, D.H. 1975. Potentials of legumes for rangelands. p. 50-61 In: Campbell, R. S. and Herbel, C. H. (Eds). Range Symposium Series. v. No. 1. Improved Range Plants. Soc. Range Manage. ; Denver, Colo.

Hotchkiss, J.R., S.E. Smith, and W.B. Miller. 1996. Persistence and single-plant productivity in nondormant alfalfa. Crop Sci. 36:336-340.

Lamb, J.F.S., L.D. Johnson, D.K. Barnes, and J.J. Marques-Ortiz. 2000. A method to characterize root morphology traits in alfalfa. Can. J. Plt. Sci. 80: 97-104.

Littell, R.C., G.A. Miliken, W.W. Stroup, and R.D. Wolfinger. 1996. SAS ${ }^{\circ}$ System for Mixed Models, SAS Institute Inc. Cary, N.C.

Lorenz, R.J. 1982. Alfalfa in Western grazing management systems. p. 1-3. In: Alfalfa for dryland grazing. USDA-ARS Agr. Info. Bull.. No. 444, U.S. Government Printing Office, Washington D.C

McKenzie, J.S., R. Paquin, and S.H. Duke. 1988. Cold and heat tolerance. p. 259-302. In: Alfalfa and Alfalfa Improvement. A.A. Hanson, D.K. Barnes, and R.R. Hill Jr. (Eds). Agronomy Monograph no. 29. ASA-CSSASSSA, Madison, Wisc.

Melton, B., J. B. Moutray, and J. H. Bouton. 1988. Geographic adaptation and cultivar selection. p. 595-620. In: Alfalfa and Alfalfa Improvement. A.A. Hanson, D.K. Barnes, and R.R. Hill Jr. (Eds) Agronomy Monograph no. 29. ASA-CSSA-SSSA, Madison, Wisc.

Murphy, J.S. and D.D. Briske. 1992. Regulation of tillering by apical dominance: Chronology, interpretive value, and current perspectives. J. Range Manage. 45:419-429.

Sanderson, M.A. and W.F. Wedin. 1989. Phenological stage and herbage quality relationships in temperate grasses and legumes. Agron. J. 81: 864-869.

SAS. 1990. SAS/STAT ${ }^{\circledR}$ User's Guide, Version 6, Fourth Edition, SAS Institute Inc, Cary, N.C.
Sheaffer, C.C., J. Grimsbo Jewett, D.K. Barnes, W.E. Lueschen, D.R. Swanson, and R. Matthison, 1997. Alfalfa persistence under infrequent cutting. J. Prod. Agr. 10:558-561.

Smith, S.R. Jr. and J.H.Bouton. 1993. Selection within alfalfa cultivars for persistence under continuous stocking. Crop Sci. 33:1321-1328.

Smith S.R. Jr., J.H. Bouton, and C.S Hoveland. 1989. Alfalfa persistence and regrowth potential under continuous stocking. Agron. J. 81:1321-1328.

Teuber, L.R., K.L. Taggard, L.K. Gibbs, M.H. McCaslin, M.A. Peterson, and D.K. Barnes. 1998. Fall Dormancy. Section A-1, p. 1-2. In C.C. Fox, R.Berberet, F.A. Gray, C.R.Grau, D.L. Jessen, and M.A. Peterson (ed.) Standard tests to characterize alfalfa cultivars, $3^{\text {rd }}$ edition. North American Alfalfa Improvement Conference. http://www.NAAIC.ORG/stdtests/Dormancy 2 .html. Accessed 27 February, 2002.

Van Keuren, R. W. and A.G. Matches. 1988. Pasture production and utilization. p. 515-538. In: Alfalfa and Alfalfa Improvement. A.A. Hanson, D.K. Barnes, and R.R. Hill Jr. (Eds) Agron. Mono. no. 29. ASA-CSSA-SSSA, Madison, Wisc. 